\author{
Јасмина Д. МОСКОВљЕВИЋ ПОПОВИЋ ${ }^{*}$ \\ Универзитет у Београду \\ Филолошки факултет
}

Оригинални научни рад

Примљен: 03. 12. 2018.

Прихваћен: 14. 02. 2019.

\title{
ЛИНЕАРИЗАЦИЈА КОНСТИТУЕНАТА У КОРЕЛАТИВНИМ КОНСТРУКЦИЈАМА СА СПАЦИЈАЛНОМ КЛАУЗОМ**
}

\begin{abstract}
Основни циљ овог рада је да се анализом грађе из савременог српског језика утврде и опишу могући обрасци линеаризације конституената у зависносложеним реченицама с корелативном конструкцијом спацијалног значења. Поредак конституената разматра се у реченичним структурама у којима управна клауза претходи зависној, као и у реченицама са инвертованим распоредом главне и зависне клаузе. Посебно се издвајају и анализирају могуће позиције корелативне речи. Уз издвајање образаца линеаризације, у раду се разматра и значај који уочене могућности линеаризације имају за категоризацију овог (под)типа зависних реченица, односно за одређење њиховог типолошког статуса унутар система зависносложених реченица савременог српског језика.

Кључне речи: зависносложене реченице, корелативне конструкције, спацијалне клаузе, обрасци линеаризације, савремени српски језик.
\end{abstract}

\section{1. Увод}

Хипотактичке реченичне структуре с корелативном конструкцијом изузетно су интересантан мада још увек недовољно испитан (под)тип сложених реченица. Присутне у свим словенским језицима, као и у другим језичким групама и породицама, у савременом српском језику реализују се као структурна варијанта различитих типова зависносложених реченица формирајући подскуп реченичних структура који готово у потпуности кореспондира са подскупом зависних реченица без корелације. ${ }^{1}$ Иако је реч о језичком феномену који је уочен, а донекле и описан још у првим граматикама са јужносло-

\footnotetext{
*jasmina.moskovljevic@fil.bg.ac.rs

** Овај рад настао је у оквиру пројекта Стандардни српски језик: синтаксичка, семантичка и прагматичка истражсивања (178004), који финансира Министарство просвете, науке и технолошког развоја Републике Србије.

${ }^{1}$ УП. Московљевић Поповић 2018.
} 
венских простора, ${ }^{2}$ неслагања и недоумица које се односе како на одређење обима и садржаја ове синтаксичке категорије, тако и на структурну репрезентацију, као и на типолошки статус реченица с корелативном конструкцијом је много. Основни циљ овог рада је да се анализом грађе из савременог језика утврде могући обрасци линеаризације конституената у једном подтипу зависносложених реченица с корелативном конструкцијом адвербијалног значења (спацијалном), да се укаже на неке организационо-структурне специфичности при реализацији овог реченичног типа, као и на значај који те специфичности имају за категоризацију ових реченица унутар система зависносложених реченица.

Опште узевши, правила линеаризације конституената у реченицама с корелативном конструкцијом слободнија су него што је то случај у кореспондентним сложеним реченицама без корелације. ${ }^{3}$ Тако, на пример, поређење сложених реченица с релативном клаузом и именичким антецедентом са структурно кореспондентним примерима реченица са корелативном речју показује значајне разлике у могућностима позиционирања појединих конституената у ова два реченична типа. У реченицама са релативном клаузом и именичким антецедентом типичан облик линеаризације конституената је онај у коме су антецедент и релативизатор (а с њим и читава релативна клауза) у контактној позицији (1а и 1б). Реченице са екстрапонираном, односно постпонованом релативном клаузом изузетно су ретке, мада ипак могуће (1в), док су реченице са препонованом релативном клаузом неграматичне (1г): ${ }^{4}$

(1)

a) Тако ни жене које су сваки час обилазиле Мару... њега не сметају. Даница која се некако једва виђаше иза попова џубета одговори мазно... И књигу која никада није била објављена написао је о томе. Само су смели предлози који су одушевљавали самог предлагача, ... како да се чаршија ослободи филова зулума ницали.

б) Тако га не сметају ни жене које су сваки час обилазиле Мару... Одговори мазно ... Даница која се некако једва виђаше иза попова џубета. Написао је и књигу која никада није била објављена о томе. Ницали су само смели предлози који су одушевљавали самог предлагача ... како да се чаршија ослободи филова зулума.

в) Тако га ни жене не сметају, које су сваки час обилазиле Мару, водиле је својим кућама и доводиле опет попу (ЛЛ, 121). ...одговори Даница полумазно, која се некако једва виђаше иза попова џубета (МШ, 24). Написао је и књигу о томе, која никада није била објављена (СрпКор, ДН). Ницали су само смели предлози како да се чаршија

\footnotetext{
2 За шири преглед схватања синтаксичке корелације у јужнословенској лингвистици в. Московљевић Поповић 2016, 2017. и тамо наведену литературу.

${ }^{3}$ Део текста и примера који се наводе у овом сегменту рада преузети су из Московљевић 2018a (5.1.5.1).

${ }^{4}$ Примери наведени у 1в, који илуструју ретке реченице са дислоцираном, дистактном релативном клаузом потичу из корпуса (прва два преузета су из Поповић 1997: 163), док су остали (1a, б и г) конструисани према њима ради лакшег поређења. Исто важи и за примере са корелативном конструкцијом (2a, б, в, г).
} 
ослободи филова зулума, који су одушевљавали самог предлагача а понекад и оне који слушају... (СрпКор, ИА).

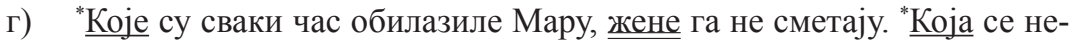
како једва виђаше иза попова џубета, Даница одговори полумазно... * Која никада није била објављена, књигу о томе је написао. "ои су одушевљавали самог предлагача... су само смели предлози како да се чаршија ослободи филова зулума ницали.

Насупрот томе, у сложеним реченицама са релативном клаузом именичке конституентске вредности и поимениченом показном заменицом у функцији корелатива могућа су сва четири распореда - два у коме су корелативна реч и релативизатор у непосредном контакту (2а и 2б), али и друга два у коме нису. При томе су и међу овим реченицама најређе оне са дислоцираном, дистактном постпонованом релативном клаузом (2в), док су реченице са препонованом релативном клаузом и заменичким антецедентом на иницијалној позицији управне клаузе (2г) у потпуности граматичне и релативно честе (мада стилски обојене $)^{5}$ :

(2)

a) Тај ко би нама угодио није се родио. Тај ко може да их сатерује на белосветске листе универзитета није се родио. Тај ко не зна да сопствене сакрије јаде, будала је. Ово што си написао нисам видео. $\underline{\underline{\text { Оно }}}$

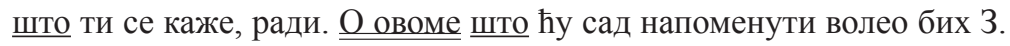

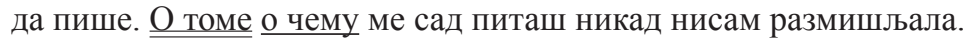

б) Није се родио тај оㅡ би нама угодио. Није се родио тај оㅡ може да их сатерује на белосветске листе универзитета. Будала је тај оㅡ не зна да сопствене сакрије јаде. Нисам видео ово што си написао. Ради

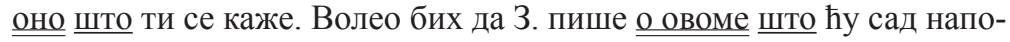
менути. Никад нисам размишљала о томе о чему ме сад питаш.

в) Тај се није родио ко би нама угодио. www.forum.redstarbelgrade.rs. ... тај се није родио ко може да их сатерује на белосветске листе универзитета. www.galaksijanova.rs. Taj је тек будала, оㅡ не зна да сопствене сакрије јаде. www.burek.com. Нисам ово видео што си написао... https://forum.b92.net. ...оно ради што ти се каже... https:// www.slobodnaevropa.org. Волео бих да 3. о овоме пише што ћу сад напоменути... https://balkankinology.net. Никад нисам о томе размишљала о чему ме сад питаш (разг.).

г) Кㅇ би нама угодио, тај се није родио. Ко може да их сатерује на белосветске листе универзитета, тај се није родио. Ко не зна да сопствене сакрије јаде, тај је тек будала. Што си написао, 으 нисам видео. Шта ти се каже, то ради. Што ћу сад напоменути, $\underline{\underline{\text { о томе }}}$ бих волео да 3. пише. $\underline{\text { о чему ме сад питаш, о томе никад нисам }}$ размишљала.

${ }^{5}$ Поједини аутори (нпр., Кордић 1995) једино реченице са препонованом зависном клаузом (2г) сврставају међу корелативне реченичне структуре. 
Значајно је уочити да се у управној клаузи сложене реченице сваки од корелатива у примерима (2a-г), који су, иначе, и значењски и функционално у потпуности кореферентни, односно кореспондентни са одговарајућом релативном клаузом, реализује на некој од позиција типичних за паралелни именички конституент - у прве три реченице то је позиција субјекта, у наредне две позиција директног објекта, а у последње две позиција неправог објекта.

Како се корелативне речи реализују и у сложеним реченицама са зависном клаузом ситуационог (околносног) адвербијалног значења и функције, па и у реченицама са спацијалном клаузом, наредни сегмент рада посвећен је представљању и дескрипцији грађе из савременог српског језика која илуструје обрасце линеаризације конституената у реченицама овог типа. ${ }^{6}$

\section{2. Линеаризација конституената у сложеним реченицама са спацијалном клаузом}

2.1. Корелативи месних клауза, заменички прилози спацијалног значења, могу се реализовати у сложеним реченицама у којима управна клауза претходи зависној, као и у реченицама у којима је зависна клауза у инвертованој позицији. У реченицама у којима управна клауза претходи зависној, корелативна реч може се налазити на крају (3), почетку (4), или унутар управне клаузе (5).

Када се реализује на финалној позицији у управној клаузи, непосредно испред субјунктора, корелативна реч може бити заменички прилог проксималног, медијалног или дисталног значења (овде, тамо, онде) ${ }^{7}$ :

(3) А можда је то било и овде где је овај велики мост... (Пол, 9). Онда сам се сетио да ћу те најсигурније наћи овде, где има девојака (СрпКор). Тако се ... нашао тамо гдје му је одвајкада и било мјесто... (ВЛ, 179). ...ако се и само за тренутак појавите тамо где вас будем чекао (СрпКор). ... или сам Бог зна где, само не онде где се рађа и умире (TpX, 252). После ће још нека трепетљичка душа отићи тамо одакле се не враћа (ЧС, 21).

Дистрибуција заменичких прилога овде, тамо и онде је равномерна и зависи од ширег контекста, целине текста, а не од унутарреченичног окружења. Насупрот томе, када се корелативна реч реализује на иницијалној позицији управне реченице, најчешће је реч о неком од спацијалних заме-

\footnotetext{
${ }^{6}$ Извори из којих је преузимана грађа наведени су на крају рада и они обухватају не само примере ексцерпиране из књижевноуметничких већ и из публицистичких текстова, као и из свих других извора који се могу наћи у Корпусу савременог српског језика (www.korpus.matf. bg.ac.rs), као и у разговорном језику и на интернету.

${ }^{7}$ У раду се ради прегледности наводе само примери са заменичким прилозима овде/тамо/ онде и субјунктором где (уз пар изузетака). За потпунији списак заменичких прилога који се реализују у функцији корелатива спацијалних клауза и кореспондентних субјунктора, в. Пипер 2010. и, посебно, Кликовац 2011.
} 
ничких прилога медијалног значења, док је са заменичким прилозима овде и онде забележен само по један пример, оба из разговорног дискурса:

(4) Тамо је моје срце, где је моја отаџбина. www.spc.rs. ...и наводно тамо лакше иде цев где је вода. www.elitemadzone.org. Тамо су богатства де олигархије премештају пословање. www.dragas.biz. Тамо су тражили тачно одређену адресу, где се данас налази уметничка галерија (СрпКор). Ту почињу неке друге цивилизације где нас Срба углавном нема (СрпКор). .... тамо су се населили у 14. веку где је већ био дошао ... народ Ђененке. https://studylib.net. Онде ти је била наша кућа где је сад та шестоспратница (разг). Овде је била моја стара кућа, баш де су сада ови темељи... www.rts.rs.

И на позицији унутар управне клаузе најчешће се бележи заменички прилог медијалног значења, мада су могуће и реченице са заменичким прилогом дисталног значења, а забележен је и један пример са заменичким прилогом проксималног значења. Пошто је употреба заменичких прилога проксималног значења и иначе чешћа у разговорном дискурсу (као егзофора), то је и једини забележени пример из писаног корпуса заправо реченица која је саставни део дијалога:

(5) Свако тамо иде где му је већи стандард и боље се живи. vesti-online. com. ...а они су управо тамо поставили камере где су ограничења нереално ниска. https:/vesti.mojauto.rs. ...она је тамо стајала где би је поставили... https://www.forum.hr. Иконе никад нису тамо враћене одакле су их узели. www.poreklo.rs. ...jep она мора тамо да буде где

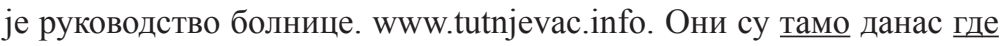
смо ми били јуче. www.znaci.net... Човек је једино онде слободан где ради из љубави... www.lovesensa.rs. ...као што се онде узима, где jе прављен тестаменат. www.overa.rs. Грки су тамо залогаји хљеба/ Гдје свога нема/ И гдје брата није... www.aleksasantic.com. Зар то није чудно да се данас, овде, опет, сретнемо нас двојица, где сам Вас први пут срео... (СрпКор).

Када је реч о позицији корелатива у односу на друге конституенте унутар матичне клаузе, он се у реченицама наведеним у (5) реализује у антевербалној, антерематској, тј. на позицији иза теме, а испред реме. ${ }^{8}$ Ово је најуочљивије у реченицама чији је предикат прост глаголски облик, у којима се корелатив налази непосредно испред глагола, док се у реченицама са именским или прилошким предикатом, као и у онима у којима је предикат сложен глаголски облик корелативна реч уз позиционирање на антевербалној, може распоредити и на позицију између копуле и предикатива, односно на позицију између помоћног и главног глагола. ${ }^{9}$

\footnotetext{
${ }^{8}$ Уп. Поповић (1997: 139 и даље) о алтернативним распоредима мобилних прилошких одредаба унутар просте реченице.

9 У претпоследњем примеру наведеном у (5), стиху Алексе Шантића, у коме се тема налази иза реме, ни корелатив се не налази на уобичајеној позицији, већ иза предиката (реме), а испред субјекта (теме). Међутим, уколико би се овај стих „превео”, односно трансформисао у реченицу
} 
Различите позиционе могућности реализације конституената у сложеним реченицама са корелативном конструкцијом и зависном клаузом спацијалног значења у постпозицији схематски су приказане у Табели 1. Од три потврђена облика линеаризације, први је најчешћи, трећи (са корелативом у интерпозицији) је ређи, док је други најређи, бар судећи по томе колико је времена било потребно да се нађу одговарајући примери.

\begin{tabular}{|l|l|l|l|l|}
\hline \multicolumn{3}{|c|}{ УПрАвнА клАузА } & \multicolumn{2}{c|}{ ЗАвиснА клАузА } \\
\hline корелатив & \multicolumn{1}{|c|}{ корелатив } & корелатив & субјунктор & \\
\hline & $\begin{array}{l}\text { А можда је то } \\
\text { било } и\end{array}$ & овде & где & је овај велики мост. \\
\hline Тамо & је моје срие & & где & је отаибина. \\
\hline & Свако тамо иде & & где & му је већи стандард. \\
\hline
\end{tabular}

Табела 1

2.2. У другом могућем распореду управне и зависне клаузе, када се зависна спацијална клауза налази испред управне, односно у препозицији, корелативна реч реализује се на једној од четири позиције. Прве три у потпуности кореспондирају са већ уоченим распоредом у реченицама у којима управна клауза претходи зависној - корелативна реч може се наћи на почетку (6), унутар (7), или на крају управне клаузе (8), док се одговарајући субјунктор спацијалног значења увек налази на иницијалној позицији инвертоване зависне клаузе:

(6) Где није било Варијага, тамо су довођени Византинци. https://www. rastko.rs. Где су деца, тамо је и будућност. www.jedinstvo.rs. Где ње нема, тамо сродници постају туђини (СрпКор). Где су људи, ту су и врапци. www.politika.rs. А где је Ганди, ту су и градска спадала (СрпКор). Одакле допире лавеж, одатле је њен будући муж. www.telegraf.rs. ...jeр где су два или три сабрани у име моје, онде сам и ја међу њима (СрпКор). Где нема тигра, онде се и зец сматра владаром. www.duhovnaizgradnja.com. Где има, ㅇде се и просипа (разг.).

У реченицама у којима се корелатив налази на почетку постпоноване управне клаузе као корелативна реч најчешће се употребљава заменички прилог медијалног значења (ту, тамо, одатле), могућа је и реализација заменичког прилога дисталног значења (онде), док је употреба прилога прок-

са основним, типичним поретком конституената, корелативна реч би се, као и у осталим примерима са именичким предикатом, могла наћи на позицији између копуле и предикатива (Залогаји хљеба су тамо грки гдје свога нема..), као и на друге две могуће позиције (Залогаји хљеба су грки тамо где..,; Тамо су грки залогаји хљеба где...). За више о правилима распоређивања глаголских енклитика, в. Поповић (ibid.: 283-364). 
сималног значења (овде, одавде) искључена и доводи до формирања неграматичне реченице: "Где није било Варијага, овде су довођени Византинци.// * Одакле допире лавеж, одавде је њен будући муж.// "Где нема тигра, овде се и зеи сматра владаром.

Исто ограничење важи и за дистрибуцију заменичких прилога у реченицама у којима се корелативна реч налази унутар постпоноване управне клаузе, у антерематској позицији. И у овом типу реченица могућа је реализација заменичких прилога медијалног и дисталног, али не и оних са проксималним значењем - заменички прилози проксималног спацијалног значења на кореферентну зависну клаузу могу да упуте катафорички, али не и анафорички. Остале могућности распоређивања конституената исте су као и у сложеним реченицама овог типа у којима управна клауза претходи зависној:

(7) Где год су нас они бранили, нас тамо више нема. www.politika.rs. ...па де сакрију, има тамо и да остане (СрпКор). Где су јој некад живели родитељи, сад јој ту живи брат (разг.). Где је некад била наша кућа, сад је тамо изграђена вишеспратница са локалима у приземљу (разг.).

Најређи су и најтеже је било доћи до примера у којима се корелатив распоређује на финалну позицију у управној клаузи - из корпуса писаног језика ексцерпиран је само један овакав пример, док преостала два потичу из разговорног језика. ${ }^{10}$ Иако ретки, овакви примери нису неграматични, па се и они издвајају као модел једног од могућих облика линеаризације конституената у реченицама с корелативном конструкцијом:

(8) Где сад стоји путоказ, вешала су некад стајала тамо, но нису била у вези с нашом причом (TX, 68). Где се појави проблем било које врсте, нас шаљу тамо да вадимо кестење из ватре (разг.). Куд се он све смуцао, никад не бих смела ни да привирим тамо! (разг.).

Уз три побројана, у сложеним реченицама са спацијалном клаузом у препозицији могућ је и четврти облик линеаризације конституената. У реченицама овог типа, које су врло честе како у писаном, тако и у разговорном језику, корелативна реч налази се на самом почетку сложене реченице, испред спацијалне клаузе:

(9) Тамо где нема вере у човека, нема никакве вере. www.politika.rs. Тамо где је рођен ... још се осећају последице тровања исцурелим изоцијанид метаном. https://www.vreme.com. Ту где си сад ти, једном сам стајао ја, овде где сам сад ја, једном ћеш бити ти! www.sokobanja.com. Овде где је сад била, све је било сушта супротност Мансфилду (СрпКор). Тамо где је историја учитељица, живот је савремен; онде где је мит водиља, прошлост је повампирена

\footnotetext{
${ }^{10}$ Уочава се и да су реченице овог типа утолико прихватљивије уколико је реченична структура сложенија. Конструисани примери са вишеструко сложеним реченицама у којима корелатив није и последња реч у исказу прихватљивији су од оних у којима се реченица завршава корелативном речју.
} 
(СрпКор). Онде где је пре све врвело од билиона, сад се опет рачуна на пфениге (СрпКор).

\begin{tabular}{|l|l|l|l|l|l|l|}
\hline \multicolumn{3}{|c|}{ Зависна клауза } & \multicolumn{3}{|c|}{ Управна клауза } \\
\hline $\begin{array}{c}\text { коре- } \\
\text { латив }\end{array}$ & $\begin{array}{c}\text { субјунк- } \\
\text { тор }\end{array}$ & $\begin{array}{c}\text { корела- } \\
\text { тив }\end{array}$ & корелатив & корелатив \\
\hline & Где & су ьуди, & my & суи врапци. \\
\hline & Где год & $\begin{array}{l}\text { сунас они } \\
\text { бранили, }\end{array}$ & нас тамо виме нема.. \\
\hline $\boldsymbol{T y}$ & Где & $\begin{array}{l}\text { сад стоји } \\
\text { путоказ, }\end{array}$ & вешала су некад стајала тамо... \\
\hline
\end{tabular}

Табела 2

И у реченицама ове структуре, односно са оваквим распоредом конституената управне и зависне клаузе могућа је употреба заменичких прилога сва три значења, али је употреба оних са медијалним значењем (тамо, ту) најчешћа. ${ }^{11}$ Корелативна реч је у структурном смислу и даље конституент управне клаузе, што је посебно уочљиво у примерима у којима би њено изостављање довело до формално и/или семантички непотпуног исказа (уп: $J a$ сам ту : *Ја сам, или, Тамо нема никаве наде : *Нема никакве наде), али је истовремено врло чврсто укотвљена и у структури зависне клаузе у којој функционише као својеврсни „пилон”, конструкциони ослонац за зависну клаузу. Могућност реализације конструкција овог типа указује на постојање својеврсног структурног континуума, односно постепеног прелаза од реченица са корелативном, ка реченицама са релативном и адвербијалном клаузом спацијалног значења: Где је некад била ледина, тамо ниче ново насеље. - Тамо/на месту где је некад била ледина ниче ново насеље. - На месту на којем је некад била ледина ниче ново насеље, односно, У шикари поред реке где је некад била ледина ниче ново насеље.

Са општетеоријске тачке гледишта, постојање реченица овакве структуре у савременом српском језику пружа додатни (иако индиректан) аргумент за Одријеву хипотезу о развоју хипотактичких реченичних структура. Наиме, Одри, а сличног су става и бројни други аутори, укључујући и К. Лемана, тврди да су се сви типови зависних реченица развили из релативних, и то релативних реченица са корелативном конструкцијом, односно да се корелативне конструкције налазе у основи свих субординираних структура у свим индоевропским језицима (Одри 1973, Леман 2015). Реченице из савременог српског језика са корелативом на иницијалној позицији сложене реченице

\footnotetext{
${ }^{11}$ У електронском Корпусу савременог српског језика (SrpKor 2013) величине 122 милиона речи корелативни пар „, овде где ” се на самом почетку сложене реченице појављује 6 пута, ,, онде где” 27 пута, а , тамо где” 680 пута.
} 
и зависном клаузом у препозицији биле би у том случају веродостојан експонент једне од прелазних фаза развоја који се кретао од корелативних ка делимично интегрисаним корелативно-релативним или корелативно-адвербијалним, а потом и недвосмислено релативним, односно недвосмислено адвербијалним реченичним структурама.

\section{3. Обрасци линеаризације конституената у реченицама} с корелативном конструкцијом спацијалног значења и њихов значај за типологију зависних реченица

Анализа грађе извршена у претходном сегменту рада показује да је распоред конституената у сложеним реченицама с корелативном конструкцијом спацијалног значења делимично условљен поретком управне и зависне клаузе у сложеној реченици. У реченицама у којима управна клауза претходи зависној могућа су три распореда - корелативна реч може се налазити на почетку, унутар, или на крају управне клаузе. Кореспондентни субјунктор спацијалног значења увек се налази на иницијалној позицији постпоноване зависне клаузе. У обрнутом распореду управне и зависне клаузе, тј. кад се зависна клауза налази у препозицији, такође су могућа три (истоветна) распореда - са корелативом на почетку, унутар или на крају управне клаузе - али је могућ и четврти, у коме се корелативна реч налази на иницијалној позицији читаве сложене реченице, у директном контакту са везником препоноване зависне клаузе. Укупно узевши, корелативне конструкције са спацијалном клаузом могу се реализовати у једном од седам могућих поредака. Дистрибуција заменичких прилога проксималног, медијалног и дисталног значења (без обзира на њихову умногоме граматикализовану природу) ${ }^{12}$ такође није слободна и варира у зависности од конкретног обрасца линеаризације који у датом исказу бива актуализован.

Утврђивање правила дистрибуције појединих корелатива, као и могућих образаца линеаризације конституената у корелативним конструкцијама спацијалног значења значајно је не само за њихов структурни опис и сагледавање могућих лексичко-конструкционих и конфигурационих варијација унутар овог типа реченица, већ и за одређење њиховог типолошког статуса, односно места у систему хипотактичких реченичних структура. О овоме различити аутори имају различите, понекад и директно супротстављене ставове - док једни сматрају да је реч о релативним клаузама, други су мишљења да је реч о клаузама адвербијалног типа. ${ }^{13}$ При томе се линеаризација конституената у корелативним конструкцијама не укључује као параметар анализе осим у врло ограниченом облику - једино што се узима у обзир је да ли се корелатив и зависна клауза налазе у контактном или дистактном положају. Међутим,

\footnotetext{
12 Уп. Пипер 2010. и Кликовац 2011.

${ }^{13}$ УП., нпр., Стевановић 1979, Московљевић 1985, Мразовић/Вукадиновић 1990, Кордић 1995, Антонић 2001, Ружић 2010, Пипер 2010, Кликовац 2011, Алановић 2018.
} 
тек сагледавање свих могућих облика линеаризације конституената у овом (под)типу реченица омогућава да се функција корелативне речи сагледа у пуном обиму. Наиме, ако се размотре позиције које корелатив заузима или може да заузме унутар сложене реченице са спацијалном клаузом, уочава се да су позиције корелатива потврђене у грађи исте оне које у простој реченици заузимају мобилне одредбе прилошке функције и значења. Тако се, као што је утврдио Љ. Поповић, слободне прилошке одредбе унутар реченице могу распоредити на четири алтернативне позиције: глобалну (позиција испред субјекатско-предикатског, одн. тематско-рематског сегмента), антерематску (позиција иза теме, а испред реме), интрарематску (позиција иза глагола а испред завршног рематског члана) и финалну (на крају реченице) (Поповић 1997: 139-144). ${ }^{14}$ На исте ове, адвербијалне позиције мобилних одредби, распоређују се и корелативи спацијалних клауза. Без обзира на образац линеаризације у оквиру кога се реализује, корелативна реч увек је у потпуности кореферентна, односно значењски и функционално еквивалентна са зависном клаузом, у овом случају спацијалног значења.

Насупрот томе, поређење са позицијама на којима може да се нађе корелатив релативних клауза са именичком конституентском вредношћу (в. 2a, б, в, г) показује да између овог типа конструкција и конструкција са спацијалном клаузом постоје значајне разлике - позиције корелатива у реченицама са зависном клаузом именичке конституентске вредности истоветне су са могућим позицијима именичких а различите од позиција у којима се реализују прилошки конституенти. ${ }^{15}$ Другим речима, конституентска вредност, односно синтаксичка функција зависне клаузе унутар читаве сложене реченице (а не у односу на неки њен део) пресудно детерминише дистрибуцију зависних клауза, како спацијалног, тако и свих других типова, па би морала да буде један од кључних параметара и приликом њихове категоризације. А примена овог параметра недвосмислено упућује на закључак да сложене реченице са спацијалном клаузом у корелативној конструкцији (било да је реч о спацијалним одредбама или допунама) не би требало сврставати међу релативне, већ међу реченице адвербијалног типа. Између осталог и због ширих општетеоријских и методолошких разлога - једино таква категоризација подразумева доследну примену функционално-семантичког (а не искључиво формалног) критеријума при опису и анализи система зависносложених реченица.

\footnotetext{
${ }^{14}$ У овом раду не издвајају се посебно примери за антерематску и интрарематску позицију јер ова дистинкција није значајна за проблем који се анализира, а навођење додатних примера знатно би продужило и оптеретило текст.

${ }^{15}$ Исто важи и за корелативе зависних клауза са придевском конституентском вредношћу - и они се у управној клаузи распоређују само на позиције конституената придевског типа.
} 


\section{ИЗВОРИ}

ВЛ - Војислав Лубарда, Преображене, Загреб: Напријед, 1979.

ЛЛ - Лаза Лазаревић, Приповетке, Београд: Просвета, 1957.

МШ - Милорад Шапчанин, Сањало, Београд: СКЗ, 1912.

Пол - Политика (30. 7. 1984.)

СрпКор - Корпус савременог српског језика. www.korpus.matf.bg.ac.rs.

СрпКор ИА - Иво Андрић, у: Корпус савременог српског језика. www.korpus. matf.bg.ac.rs.

СрпКор ДН - Данило Ненадић, у: Корпус савременог српског језика. www.korpus. matf.bg.ac.rs.

ТрХ - Иво Андрић, Травничка хроника, Београд: Просвета, 1967.

ТХ - Томас Харди, Незнани Џуд, Београд: Нолит, 1965.

ЧС - Чедомир Станковић, Жаришта, Београд: Народна књига, 1980.

ЕлЕКтРОНСКИ извоРи: www.rts.rs. www.spc.rs. www.politika.rs. www.elitemadzone.org. www.dragas.biz. https://studylib.net. www.in4s.net. www. duhovnaizgradnja.com. https://zena.blic.rs. www.vesti-online.com. www. znaci.net. www.galaksijanova.rs. https://vesti.mojauto.rs. www.telegraf.rs. https://www.forum.hr. www.poreklo.rs. www.tutnjevac.info. www.jedinstvo. rs. www.forum.redstarbelgrade.rs. www.lovesensa.rs. www.overa.rs. www. aleksasantic.com. www.sabornihram.com. www.rastko.rs. www.vreme.com. www.sokobanja.com. www.nedeljnik.rs. www.burek.com. https://www.avlija.me. www.media.ba. https://forum.b92.net.

\section{ЛИТЕРАТУРА}

Алановић 2018: Миливој Алановић, Граматички статус спацијалне клаузе - на други поглед, Јужнословенски филолог, LXXIV/2, (у штампи).

Антонић 2001: Ivana Antonić, Vremenska rečenica, Sremski Karlovci: Izdavačka knjižarnica Zorana Stojanovića.

Кликовац 2011: Душка Кликовац, О месним клаузама у српском језику, $\mathrm{Ha-}$ учни састанак слависта у Вукове дане, 40/3, 47-72.

Кордић 1995: Snježana Kordić, Relativna rečenica, Zagreb: Matica hrvatska.

Леман 2015: Christian Lehmann, Thoughts on grammaticalization, 3rd edition, Berlin: Language Science Press.

Московљевић 1985: Jasmina Moskovljević, Upotreba korelativa i supstituenata zavisnih rečenica u srpskohrvatskom jeziku (neobjavljeni magistarski rad, Filološki fakultet, Beograd).

Московљевић Поповић 2016: Jasmina Moskovljević Popović, O korelativnim konstrukcijama u južnoslovenskoj lingvistici (I), Анали Филолошког факултета, XXVIII/1, 337-346. 
Московљевић Поповић 2017: Jasmina Moskovljević Popović, O korelativnim konstrukcijama u južnoslovenskoj lingvistici (II), Анали Филолошког факултета, XXIX/2, 101-110.

Московљевић Поповић 2018: Јасмина Московљевић Поповић, Корелативне конструкције у савременом српском језику, у: Српска славистика. Зборник радова српске делегаџије на XVI међународном конгресу слависта. Том I. Језик, Београд: ССДС, 229-244.

Московљевић Поповић 2018а: Јасмина Московљевић Поповић, Корелативне конструкиије: теоријске основе анализе, Београд: Филолошки факултет.

Мразовић/Вукадиновић 1990: Pavica Mrazović, Zora Vukadinović, Gramatika srpskohrvatskog jezika za strance, Sremski Karlovci: Izdavačka knjižarnica Zorana Stojanovića - Novi Sad: Dobra vest.

Одри 1973: Jean Haudry, Parataxe, hypotaxe et corrélation dans la phrase latine, Bulletin de la Société de linguistique 68: 147-186.

Пипер 2010: Предраг Пипер, О реченицама са спацијалном клаузом у српском језику, Јужнословенски филолог, LXVI, 387-406.

Поповић 1997: Љубомир Поповић, Ред речи у реченици, Београд: Друштво за српски језик и књижевност Србије.

Ружић 2010: Владислава Ружић, О класификацији зависних реченица у српском језику, Српски језик, XV, 105-119.

Стевановић 1979: Михаило Стевановић, Савремени српскохрватски језик.

II. Синтакса, Београд: Научна књига.

Jasmina D. Moskovljević Popović

\section{LINEARIZATION OF CONSTITUENTS IN COMPLEX SENTENCE WITH CLAUSE OF PLACE IN CORRELATIVE CONSTRUCTION}

\section{Summary}

The main goal of this paper is to identify and describe possible linearization patterns of constituents in a complex sentence with a clause of place in correlative construction. The order of constituents is analyzed in sentence structures with the main clause preceding the dependent one, as well as in sentences with the inversion of the main and dependent clauses. Possible positions of correlative words are identified and analyzed separately. The paper also looks at the significance of the established linearization patterns for the categorization of complex sentences of this (sub)type, namely, for defining their typological status within the complex sentence system of the Serbian Language.

Keywords: complex sentences, correlative constructions, spacial clauses, patterns of linearization, contemporary Serbian language. 